Article

\title{
Set the Controls for the Heart of the Maths. The Protective Factor of Resilience in the Face of Mathematical Anxiety
}

\author{
Rubén Trigueros ${ }^{1}$, José M. Aguilar-Parra ${ }^{1}{ }^{1}$, Isabel Mercader ${ }^{1, *}$, Juan M. Fernández-Campoy ${ }^{1}$ \\ and José Carrión ${ }^{2, *}$ \\ 1 Department of Psychology, Hum-878 Research Team, Health Research Centre, University of Almeria, \\ 04120 Almeria, Spain; rtr088@ual.es (R.T.); jmaguilar@ual.es (J.M.A.-P.); jfc105@ual.es (J.M.F.-C.) \\ 2 Department of Education, University of Almeria, 04120 Almeria, Spain \\ * Correspondence: imercade@ual.es (I.M.); jcarrion@ual.es (J.C.)
}

Received: 24 August 2020; Accepted: 18 September 2020; Published: 26 September 2020

check for updates

\begin{abstract}
According to the latest PISA report, the level of mathematical competence of Spanish students is far behind the rest of the OECD countries. One of the main reasons for this is the animosity that students feel towards this subject. Therefore, this study aims to analyze the processes of overcoming the vicissitudes of mathematical anxiety with respect to motivation, metacognitive strategies and academic performance. This study involved 1742 high school students with an average age of 14.87. To analyze the variables of the study, descriptive statistical analyses and a model of structural equations were carried out. The results revealed a negative correlation between resilience and anxiety. In turn, resilience was positively related to motivation and metacognitive strategies, while anxiety was negatively related to motivation and metacognitive strategies. Motivation was positively related to metacognitive strategies and academic performance; finally, metacognitive strategies were positively related to academic performance.
\end{abstract}

Keywords: resilience; maths; anxiety; motivation; academic performance

\section{Introduction}

According to the PISA report of 2018, Spanish students occupy the last positions within the OECD countries in the area of mathematics, specifically with 481 points compared to the 489 average of OECD countries [1]. Moreover, 37.8\% of Spanish students do not reach level 2 in the use of algorithms, formulas, procedures or elementary conventions [1]. These educational results highlight the problems inherent in the teaching of mathematics in the Spanish educational system, which is incapable of motivating students, and pays more attention to achieving curricular objectives than to the students' own comprehensive development [2]. In addition, this pressure on results and the deficient approach to teaching and learning in the area of mathematics causes students to perceive this area with a certain hostility, causing them anxiety and holding back the students' interest in learning and achieving academic objectives [3]. Therefore, the aim of this study is to analyze the processes of overcoming the vicissitudes of mathematical anxiety with respect to motivation, metacognitive strategies and academic performance.

\subsection{Academic Resilience}

Resilience represents one of the main psychological characteristics associated with psychological and emotional well-being and academic success [4]. The meta-theory of resilience was one of the first theories to attempt to conceptualize this construct [5]. This metatheory understands resilience as 
a psychological mechanism present in all people that allows them to adapt to and overcome the various stressful situations faced by individuals at any time in their lives [5]. However, this meta-theory has certain limitations, since it understands resilience as a linear activation mechanism without taking into account other paths [6]. In this way, the individual faces a stressful event that, once overcome, returns to equilibrium by raising their level of homeostasis, learning new skills and acquiring tools with which to overcome another future stressful event [7]. In addition, recent studies in the field of education have highlighted that emotions facilitate the process of resilience and exert a protective role [8]. Therefore, resilience is currently understood as a construct linked to protective and vulnerable factors inside and outside the individual that influence the individual's adaptation to vicissitudes and stressful events that lead to a loss of homeostasis [9].

The importance of resilience in academic contexts is due to the fact that certain students who are exposed to stressful and adverse situations emerge stronger without developing any psychological disorder [10]. In this sense, resilience has been positively related to emotional intelligence [11], internal motivation [12] and academic performance [13]. In contrast, resilience has been negatively related to stress [14], test anxiety [8] and burnout [15].

\subsection{Mathematical Anxiety}

Anxiety is understood as an exaggerated emotional reaction that is difficult to control, produced by an external stimulus that is considered by the individual as threatening, producing physiological and behavioral changes in the subject [16]. In this sense, when students are in mathematics class, they are faced with prejudice and family, social and personal pressures, focused on achieving good academic performance that allows them to face the future with a better perspective [17]. Mathematical anxiety can cause inhibition, defenselessness, paralysis and mental disorganization in students when they are required to solve a mathematical problem, thus impairing their performance in class [18]. In this way, mathematical anxiety can be understood as a state when students perceive mathematics as a potentially threatening element that disappears once the emotion has passed; or as a trait linked to the personality of the students, which, due to their own personalities, makes them more likely to experience this emotion [19].

Until now, studies on anxiety in education have shown a negative relationship with respect to academic performance [20], content assimilation [21] and metacognitive processes [22]. In contrast, anxiety, in an academic context, has been positively related to stress [23], frustration [24] and emotional distress [25].

\subsection{Motivation}

Young people's motivation for learning and interest in a particular subject has an important influence on their school performance in any area, including mathematics [26]. In this sense, motivation is an internal state that activates, directs and maintains a person's behavior towards specific goals or objectives. In a way, it refers to the impulse that moves a person to perform certain actions and to persist in them for their completion, that is, motivation is what gives energy and direction to behavior-it is the cause of behavior [13].

However, motivation is not something that arises spontaneously, but is rather influenced by the experiences of the individual and the social context [26]. In this sense, the self-determination theory (SDT) states that the influence of the social context is through two opposing forms, autonomy support versus controlling style. Autonomy support refers to the promotion of physical, psychological and social self-development and to the student's own initiative. On the other hand, a controlling style on the part of the teacher is perceived by the student as the origin of his or her own behavior by diminishing his or her own initiative, personal self-knowledge and active participation in the classroom.

Depending on the predominant role in the social context, and especially the teacher, it may affect the motivation of the student. SDT suggests that motivation can be of three different types, intrinsic motivation, extrinsic motivation (which includes four different types of regulation) and 
amotivation [27]. Intrinsic motivation refers to when the subject commits to the activity for the simple fact of enjoying and having fun with it, therefore, the activity becomes an end in itself; integrated regulation refers to when behaviors are ordered and equated in a meaningful and hierarchical way according to the values and needs that we have; identified regulation refers to when the individual identifies with the activity he or she performs; introjected regulation refers to the establishment of a series of obligations to carry out the action and which are linked to self-approval, and to the avoidance of negative emotions and feelings; external regulation refers to the carrying out of the action due to the search for desired consequences or to avoid punishment; and, finally, amotivation is understood as the complete absence of motivation or desire to act.

There is a long tradition of research focusing on the role of motivation in academic achievement [28]. In this sense, internal motivation has shown a positive relationship with respect to academic performance [29], resilience [13] and metacognitive processes [30]. In contrast, external motivation for exams has been positively related to emotional distress [31], frustration [32] and even dropping out of school [33]. However, current studies, particularly in the area of mathematics, have hardly ever analyzed the influence of motivation on metacognitive strategies and academic performance, after having been influenced by mathematical resilience and anxiety.

\subsection{Metacognitive Strategies}

Traditionally and even today, the teaching of mathematics has been carried out using algorithmic procedures that have been taken out of context, without taking into account their applicability in everyday life, and using formulas that have been learned by heart [34]. In this way, students only apply what they have assimilated in fictitious situations created by the teacher, and the content has no real meaning for them. Likewise, results are prioritized without concern for the mental processes that the student develops when solving mathematical exercises or problems. Despite this, for teaching to be meaningful, it is necessary to develop learning in which the student is the protagonist and deals with his or her own knowledge in a conscious and reflexive way [35].

Thus, metacognition constitutes the highest level of mental activity, since it comprises the knowledge we have about what it means to think, how thinking processes work, learning skills or strategies in relation to different types of tasks, as well as knowledge or beliefs about oneself [36]. In this sense, metacognitive strategies are those that allow students to observe their own learning process by using various resources to plan, control and evaluate their own progress [37].

Studies focusing on metacognitive strategies in the field of education have shown a positive relationship with regard to academic performance [34], the achievement of teaching objectives [38], reading comprehension [39] and the learning of a second language [40].

\subsection{Objectives and Hypotheses}

As shown above, the aim of the present study is to analyze the influence of resilience and mathematical anxiety on the motivation, metacognitive strategies and academic performance of students in compulsory secondary education. In this sense, studies until now have only established dyadic relationships between two variables (e.g., mathematical resilience and anxiety, mathematical anxiety and motivation, etc.), not providing an overview of how strategies to overcome stressful events and their relationship with mathematical anxiety affect students' motivational and cognitive processes. In this way, and in virtue of the studies previously shown, it is hypothesized that: the correlation between academic resilience and mathematical anxiety will be negative; resilience will be positively related to academic motivation and metacognitive strategies; mathematical anxiety will be negatively related to academic motivation and metacognitive strategies; motivation will be positively related to metacognitive strategies and academic performance; and, finally, metacognitive strategies will be positively related to academic performance. 


\section{Methods}

\subsection{Participants}

In order to carry out this study, 1742 high school students (958 boys and 784 girls) were required to participate. The age of the students was between 13 and 16 years, with a mean of $14.87(\mathrm{SD}=1.17)$.

The students were schooled in several secondary schools in the province of Almeria (Spain).

\subsection{Measurements}

Academic resilience. The Cassidy Academic Resilience Scale [41] was used, specifically the Spanish version [42]. The scale is made up of 30 items distributed among three factors, with 9 items for reflection and adaptation to seeking help (e.g., I would use my past successes to help motivate myself), 14 items for perseverance (e.g., I would just give up) and 7 items for negative affect and emotional response (e.g., I would probably get annoyed). The score of the items with a positive connotation was inverted so that a high score indicates greater academic resistance. Students responded by using a Likert scale ranging from 1 (probable) to 5 (unlikely).

Mathematical anxiety. The Fennema-Sherman Scale was used [43]. This scale is made up of 12 items measuring a single factor (e.g., When I do maths problems my mind goes blank and I am not able to think clearly). Students responded by using a Likert scale ranging from 1 (strongly disagree) to 5 (strongly agree).

Academic motivation towards learning. The Academic Self-Regulation Scale by Vansteenkiste, Sierens, Soenens, Luyckx and Lens [44] was used, specifically the Spanish version [45]. This scale is made up of 24 items distributed among six factors, being: intrinsic motivation (e.g., Because I like it), extrinsic motivation (integrated regulation (e.g., Because learning is a fundamental part of me), identified regulation (e.g., Because it's important for me), introjected regulation (e.g., Because I would be ashamed if I failed), external regulation (e.g., Because it is obligatory)) and amotivation (e.g., But I really feel like I'm wasting my time). Students responded using a Likert scale ranging from 1 (not true) to 7 (completely true).

The Self-Determination Index (SDI) was calculated to assess academic motivation. The calculation of this index is made by means of the following formula: $(3 \times$ intrinsic motivation, $2 \times$ integrated regulation and $1 \times$ identified regulation $)-(1 \times$ introjected regulation, $2 \times$ external regulation and $3 \times$ de-motivation). This index has been used in numerous studies [46] and is valid and reliable.

Metacognitive strategies. The Motivated Strategies for Learning Questionnaire [47] was used, specifically the Spanish version [48]. This single factor is composed of 12 items (e.g., I ask myself questions to make sure I understand the material I have been studying in this class). Students responded using a Likert scale ranging from 1 (not true) to 5 (completely true).

Academic performance. To analyze the performance of secondary school students in the subject of mathematics, their grades at the end of the academic year were taken into consideration. In this sense, the grades were distributed as follows: 5 (outstanding), 4 (notable), 3 (good), 2 (passed) and 1 (failed).

\subsection{Procedure}

Initially, the approval of the bioethics committee of the University of Almeria was obtained in order to start this study (Ref. UALBIO 2019/213). Once obtained, the management teams of several secondary schools were contacted, explaining in detail the objective of the present study and requesting their support. Subsequently, those educational centers that accepted to participate in the study were contacted, explaining to them the objective of the study and requesting their participation. Before they could participate in the study, they had to provide an informed consent signed by their parents or legal guardians.

The questionnaires were filled out at the beginning of the mathematics class, indicating that the answers would be anonymous and confidential. In addition, a member of the research group 
was present to answer any questions that might arise. The completion of the questionnaires took 25 minutes.

\subsection{Data Analysis}

The statistical analyses performed in this study were descriptive statistics: mean, standard deviation and bivariate correlations, in addition to reliability analysis, using the SPSS v25 statistical package. Subsequently, a structural equation model (SEM) was performed to analyze the predictive relationships established in the hypothesized model, using the AMOS v20 statistical package.

A bootstrapping of 5000 interactions was used to perform the SEM, together with the maximum likelihood method. To analyze the goodness of the hypothesized model (Figure 1), the following indices were taken into account [49]: $\chi^{2} / \mathrm{df}$, with values between 2 and 3; Comparative Fit Index (CFI), Incremental Fit Index (IFI) and Tucker Lewis Index (TLI), with values above 0.95; Root Mean Square Error of Approximation (RMSEA) plus its 90\% confidence interval, with values below 0.06; and Standardized Root Mean Square Residual (SRMR), with values below 0.08. Nevertheless, these indices should be interpreted with caution as they can be restrictive when the model is very complex [50].

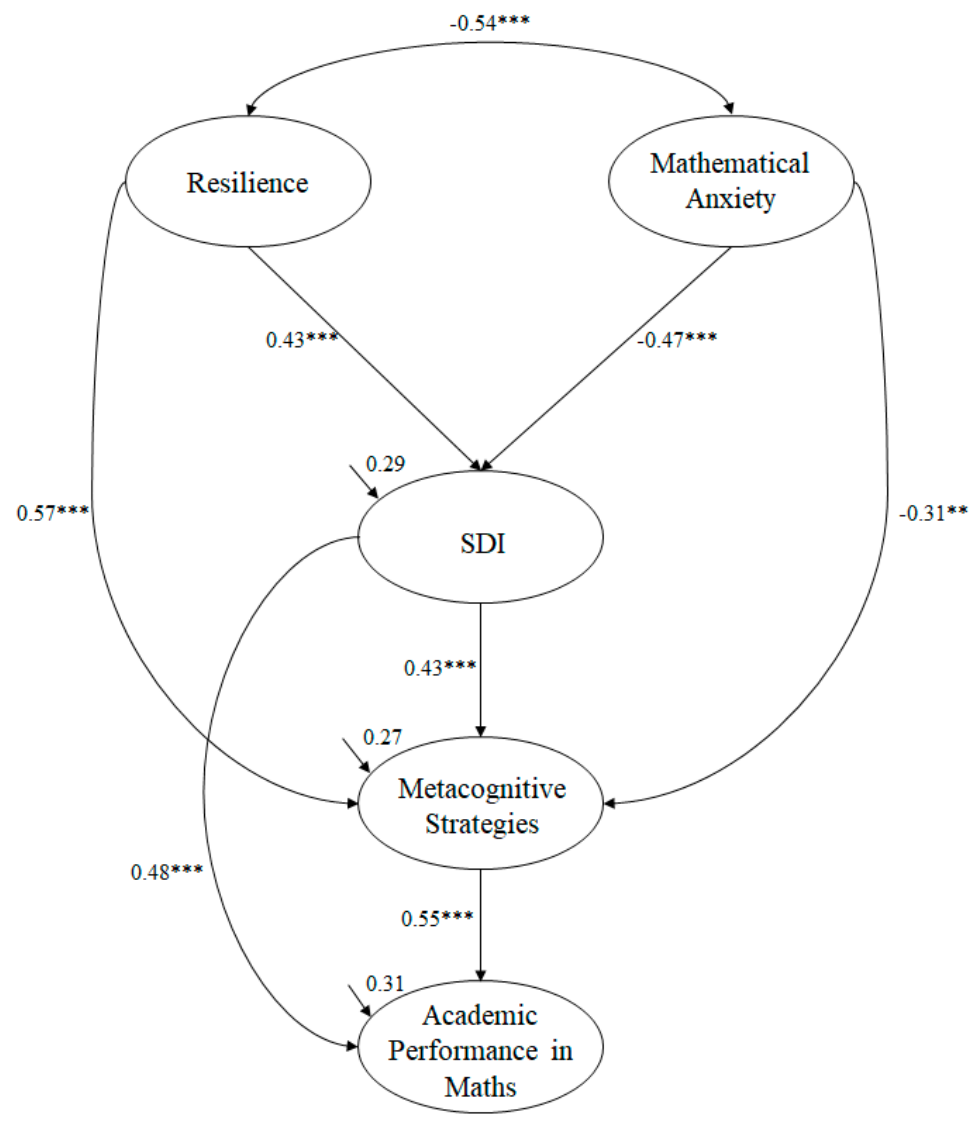

Figure 1. Structural equation model showing the relationships between variables. ${ }^{* *} p<0.01 ;{ }^{* * *} p<0.001$.

\section{Results}

\subsection{Preliminary Analysis}

The mean, standard deviation and bivariate correlations can be seen in Table 1. The correlations reflected a positive relationship between resilience, motivation, metacognitive strategies and academic performance. In contrast, the correlation was negative between mathematical anxiety and the rest of the variables. In addition, reliability analyses are shown in Table 1, with all scores above 80 [51]. 
Table 1. Mean, standard deviation, analysis of internal consistency and bivariate correlations.

\begin{tabular}{|c|c|c|c|c|c|c|c|c|}
\hline Factors & $\mathbf{M}$ & SD & $\alpha$ & 1 & 2 & 3 & 4 & 5 \\
\hline 1. Academic Resilience & 1.82 & 1.06 & 0.81 & & $-0.42 * * *$ & $0.39 * * *$ & $0.48^{* * *}$ & $0.55^{* * *}$ \\
\hline 2. Mathematics Anxiety & 2.12 & 1.47 & 0.82 & & & $-0.27 * *$ & $-0.63^{* * *}$ & $-0.54^{* * *}$ \\
\hline 3. Academic Motivation & 2.14 & 1.32 & - & & & & $0.64^{* * *}$ & $0.75^{* * *}$ \\
\hline 4. Metacognition Strategies & 1.96 & 1.33 & 0.84 & & & & & $0.64^{* * *}$ \\
\hline 5. Academic Performance & 1.88 & 1.34 & - & & & & & \\
\hline
\end{tabular}

\subsection{Structural Equation Model}

In testing the hypothesized predictive relationship model on math students (Figure 1), it has revealed the following adjustment rates: $\chi^{2}(371 . \mathrm{N}=1742)=894.63, p<0.001 ; \chi^{2} / \mathrm{df}=2.41 ; \mathrm{CFI}=0.96$; $\mathrm{IFI}=0.96 ; \mathrm{TLI}=0.96 \mathrm{RMSEA}=0.053(\mathrm{CI} 90 \%=0.049-0.058) ; \mathrm{SRMR}=0.041$.

The direct relationships obtained between the different factors comprising the model are described as follows:

(a) The correlation between academic resilience and mathematical anxiety was negative ( $\beta=-0.54$, $p<0.001)$.

(b) Academic resilience was positively related to SDI $(\beta=0.43, p<0.001)$ and metacognitive strategies $(\beta=0.57, p<0.001)$.

(c) Mathematical anxiety was negatively related to SDI $(\beta=-0.47, p<0.001)$ and metacognitive strategies $(\beta=-0.31, p<0.01)$.

(d) SDI was positively related to metacognitive strategies $(\beta=0.43, p<0.001)$ and academic performance $(\beta=0.48, p<0.001)$.

(e) Metacognitive strategies were positively related to academic performance $(\beta=0.55, p<0.001)$.

As for the indirect relations, these were as follows:

(a) Academic resilience was positively related to academic performance $(\beta=0.11, p<0.053)$.

(b) Mathematical anxiety was negatively related to academic performance $(\beta=-0.14, p<0.061)$.

\section{Discussion}

The aim of this study was to analyze the influence of resilience and mathematical anxiety on motivation, metacognitive strategies and academic performance of students in compulsory secondary education. To this end, this study has taken a holistic view of students' motivational processes and their effect on academic performance in the area of mathematics, taking into account that this subject tends to generate a certain animosity in students because they perceive it as a source of stress and anxiety [52]. In this regard, several studies have suggested the need to develop strategies within the classroom to enable students to manage and overcome stress and anxiety when faced with the academic challenge of mathematics, so that they can generate adaptive behaviors that manifest themselves in greater mastery and academic performance [53].

The results of the present study have shown evidence that academic resilience and mathematical anxiety were negatively correlated. These results can be compared with various studies both nationally and internationally, where the protective nature of resilience to stressful situations has been shown. A study by Johnston-Wilder, Brindley and Dent [54] of primary and secondary school students showed evidence that students with high levels of resilience could handle stressful situations efficiently and were less likely to experience mathematical anxiety. Similarly, a study conducted by Trigueros, Padilla, Aguilar-Parra, Rocamora, Morales-Gázquez and López-Liria [55] with university students showed that students with high levels of resilience felt less anxiety when faced with an exam. Therefore, the results of the present study are consistent with previous studies in the academic field. In this sense, students' successive experiences in academic contexts and the challenges they have faced are key to building 
resilience $[8,13]$. Thus, the more resilient students are, the better they will be able to manage their anxiety in the face of a new academic challenge.

The results of this study have shown that academic resilience positively predicted academic motivation and metacognitive strategies. However, mathematical anxiety negatively predicted academic motivation and metacognitive strategies. However, we are not aware of any studies that have analyzed these relationships or existing studies that have analyzed these relationships in isolation. In this regard, a study by Jowkar, KojurI, Kohoulat and Hayat [12] with medical students found that those students with high levels of academic resilience showed a greater predisposition towards intrinsic motivation. Similarly, a study carried out by De La Fuente, Fernández-Cabezas, Cambil, Vera, González-Torres and Artuch-Garde [56] with university students showed that those students who had high levels of resilience had a greater facility for using coping strategies that applied to different tasks and activities facilitating learning through the use of metacognitive strategies. On the other hand, a study conducted by Field, Evans, Bloniewski and Kovas [57] with elementary and high school students found that students who were more anxious about mathematics showed greater anxiety, which negatively affected classroom experiences and, consequently, their motivation towards mathematics. Similarly, several studies in the academic field $[58,59]$ have shown that mathematical anxiety has a negative influence on the adoption of metacognitive strategies in academic tasks and exercises. Therefore, the results achieved in this study are in line with the various previous studies in the academic field. In this way, resilience plays a protective role against anxiety-generating stressful events. Thus, encouraging coping strategies through challenges appropriate to the level of the students will promote motivation and the learning and effective use of metacognitive strategies that will favor the assimilation of mathematical contents and concepts.

Finally, the results of this study have shown that motivation predicted the use of metacognitive strategies and academic performance, and metacognitive strategies positively predicted academic performance. These results are similar to previous research in the field of mathematics [60], although as mentioned above, the psychological coping factors and the effect of possible psychological effects of the stressful events were not taken into consideration. In this sense, a study carried out by Berger and Karabenick [61] with high school students showed that the internal motivation of the student favors the use of learning strategies that help the assimilation and consolidation of knowledge. Similarly, a study by Rodríguez, Piñeiro, Gómez-Taibo, Regueiro, Estévez and Valle [62] revealed that students with high homework motivation showed higher academic performance, greater conceptual depth and better grades compared to students with higher external motivation. These results can be explained by the fact that students make use of metacognitive strategies to facilitate information processing by selecting, organizing and regulating cognitive processes [63]. However, it is essential that students show an interest in the subject, i.e., an intrinsic motivation, since it requires a great effort to plan and consciously use strategies to facilitate academic performance [64].

Despite the results achieved in this study, it is necessary to detail a number of limitations. Firstly, this is a cross-sectional study, since there is no manipulation of any variable in the study. For this reason, causal relationships cannot be established, and the reader is left with the choice of possible explanations for the relationships between the study variables. Thus, we suggest that future studies provide longitudinal data that allow an estimation of the causal effects of academic resilience and mathematical anxiety on students' psychological and motivational variables.

\section{Conclusions}

This study contributes to the area of teaching and promoting mathematics among students, since it has taken into account the emotions, motivation and attribution of secondary school students in this area. In this way, through this study, valuable pedagogical implications can be deduced so that teachers integrate into their teaching situations that encourage the reflection of students. In this sense, there are currently different methodologies that can be implemented in the classroom (e.g., gamification, flipped classroom) that pose a "fun challenge" for students, and that help them maintain their interest in 
the classroom [65,66], promoting the consolidation of knowledge and the assimilation of content. Furthermore, teachers need to be aware of the following: (a) the importance and impact of the classroom atmosphere, as it affects students' interest, enthusiasm, commitment and motivation during instruction or class time. In this way, teachers should create a classroom atmosphere that fosters comfort, confidence and good relationships among peers and with the teacher. To this end, it is essential that the teacher be accessible and not distant or intimidating, should understand the mistakes and doubts of the students and, finally, should try to connect and interact with their students; (b) teachers should provide learning environments that promote autonomy over external control. When learning is achieved through procedures that support adolescent participation, a sense of self-determination and the overcoming of difficulties towards learning is enhanced; (c) teachers should develop tests that can better reflect the content that has been taught during classes, rather than presenting challenges and extra tests that put stress on the students; and (d) education policies, as far as mathematics is concerned, should aim at using and doing mathematics in a wide variety of situations and contexts as it is an important element contributing to literacy and the development of mathematical competence.

Author Contributions: Conceptualization, R.T. and J.C.; methodology, J.M.A.-P.; formal analysis, J.M.A.-P.; investigation, J.M.F.-C.; data curation, I.M. and J.C.; writing-original draft preparation, R.T.; writing-review and editing, R.T. and I.M. All authors have read and agreed to the published version of the manuscript.

Funding: This research received no external funding.

Conflicts of Interest: The authors declare no conflict of interest.

\section{References}

1. Ministerio de Educación, Ciencia y Deporte. PISA 2018. Programa para la Evaluación Internacional de los Estudiantes; Informe Español: Madrid, Spain, 2019.

2. Muñiz-Rodríguez, L.; Alonso, P.; Rodríguez-Muñiz, L.J.; Valcke, M. ¿Hay un vacío en la formación inicial del profesorado de matemáticas de Secundaria en España respecto a otros países? Rev. Educ. 2016, 372, 111-140.

3. Namkung, J.M.; Peng, P.; Lin, X. The relation between mathematics anxiety and mathematics performance among school-aged students: A meta-analysis. Rev. Educ. Res. 2019, 3, 459-496. [CrossRef]

4. Kristjánsson, K. Aristotle, Emotions, and Education; Routledge: Abingdon, UK, 2016.

5. Richardson, G.E. The metatheory of resilience and resiliency. J. Clin. Psychol. 2002, 3, 307-321. [CrossRef]

6. Crane, M.F.; Searle, B.J.; Kangas, M.; Nwiran, Y. How resilience is strengthened by exposure to stressors: The systematic self-reflection model of resilience strengthening. Anxiety Stress Coping 2019, 32, 1-17. [CrossRef]

7. Fletcher, D.; Sarkar, M. Mental fortitude training: An evidence-based approach to developing psychological resilience for sustained success. J. Sport Psychol. Action 2016, 7, 135-157. [CrossRef]

8. Van Hoek, G.; Portzky, M.; Franck, E. The influence of socio-demographic factors, resilience and stress reducing activities on academic outcomes of undergraduate nursing students: A cross-sectional research study. Nurse Educ. Today 2019, 72, 90-96. [CrossRef]

9. Sarkar, M. Psychological resilience: Definitional advancement and research developments in elite sport. Int. J. Stress Prev. Wellbeing 2017, 1, 1-4.

10. Robertson, J.; Schiöler, L.; Toren, K.; Söderberg, M.; Löve, J.; Waern, M.; Rosengren, A.; Åberg, M.A.I. Mental disorders and stress resilience in adolescence and long-term risk of early heart failure among Swedish men. Int. J. Cardiol. 2017, 243, 326-331. [CrossRef]

11. Magnano, P.; Craparo, G.; Paolillo, A. Resilience and emotional intelligence: Which role in achievement motivation. Int. J. Psychol. Res. 2016, 1, 9-20. [CrossRef]

12. Jowkar, B.; Kojuri, J.; Kohoulat, N.; Hayat, A.A. Academic resilience in education: The role of achievement goal orientations. J. Adv. Med. Educ. Prof. 2014, 1, 33-38.

13. Trigueros, R.; Aguilar-Parra, J.M.; Cangas, A.J.; Bermejo, R.; Ferrandiz, C.; López-Liria, R. Influence of emotional intelligence, motivation and resilience on academic performance and the adoption of healthy lifestyle habits among adolescents. Int. J. Environ. Res. Public Health 2019, 16, 2810. [CrossRef] [PubMed]

14. Ozsaban, A.; Turan, N.; Kaya, H. Resilience in nursing students: The effect of academic stress and social support. Clin. Exp. Neurol. 2019, 9, 71-78. [CrossRef] 
15. Ríos-Risquez, M.I.; García-Izquierdo, M.; Sabuco-Tebar, E.D.L.A.; García, C.C.; Martinez-Roche, M.E. An exploratory study of the relationship between resilience, academic burnout and psychological health in nursing students. Contemp. Nurse 2016, 4, 430-439. [CrossRef] [PubMed]

16. Tuma, A.H.; Maser, J.D. Anxiety and the Anxiety Disorders; Erlbaum: Hillsdale, NJ, USA, 1985.

17. Hill, F.; Mammarella, I.C.; Devine, A.; Caviola, S.; Passolunghi, M.C.; Szúcs, D. Maths anxiety in primary and secondary school students: Gender differences, developmental changes and anxiety specificity. Learn. Individ. Differ. 2016, 48, 45-53. [CrossRef]

18. Whyte, J.; Anthony, G. Maths anxiety: The fear factor in the mathematics classroom. N. Z. J. Teach. Work 2012, 1, 6-15.

19. Trigueros, R.; Aguilar-Parra, J.M.; Álvarez-Hernández, J.F.; Cangas, A.J. Adaptation and validation of the mind-wandering questionnaire (MWQ) in physical education classes and analysis of its role as mediator between teacher and anxiety. Sustainability 2019, 11, 5081. [CrossRef]

20. Thomas, C.L.; Cassady, J.; Heller, M.L. The influence of emotional intelligence, cognitive test anxiety, and coping strategies on undergraduate academic performance. Learn. Individ. Differ. 2017, 55, 40-48. [CrossRef]

21. Wiguna, R.I.; Dwidiyanti, M.; Sari, S.P. The influence of mindfulness on the decreasing anxiety in nursing students to support academic learning: A literature review. Holist. Nurs. Health Sci. 2018, 1, 24-34. [CrossRef]

22. González, A.; Carrera-Fernández, M.V.; Paoloni, P.V. Hope and anxiety in physics class: Exploring their motivational antecedents and influence on metacognition and performance. J. Res. Sci. Teach. 2017, 54, 558-585. [CrossRef]

23. Breedvelt, J.J.F.; Amanvermez, Y.; Harrer, M.; Karyotaki, E.; Gilbody, S.; Bockting, C.L.H.; Cuijpers, P.; Ebert, D.D. The effects of meditation, yoga, and mindfulness on depression, anxiety, and stress in tertiary education students: A meta-analysis. Front. Psychiatry 2019, 10, 193. [CrossRef]

24. Rehman, A.U. Academic anxiety among higher education students of India, causes and preventive measures: An exploratory study. Int. J. Mod. Soc. Sci. 2016, 2, 102-116.

25. Martínez-Monteagudo, M.C.; Inglés, C.J.; Granados-Alós, L.; Aparisi, D.; García-Fernández, J.M. Trait emotional intelligence profiles, burnout, anxiety, depression, and stress in secondary education teachers. Pers. Individ. Differ. 2019, 142, 53-61. [CrossRef]

26. Lazowski, R.A.; Hulleman, C.S. Motivation interventions in education: A meta-analytic review. Rev. Educ. Res. 2016, 86, 602-640. [CrossRef]

27. Sun, H.; Li, W.; Shen, B. Learning in physical education: A self-determination theory perspective. J. Teach. Phys. Educ. 2017, 36, 277-291. [CrossRef]

28. Vasconcellos, D.; Parker, P.D.; Hilland, T.; Cinelli, R.; Owen, K.B.; Kapsal, N.; Lee, J.; Antczak, D.; Ntoumanis, N.; Ryan, R.M.; et al. Self-determination theory applied to physical education: A systematic review and meta-analysis. J. Educ. Psychol. 2019. [CrossRef]

29. Zhou, M. Moderating effect of self-determination in the relationship between Big Five personality and academic performance. Pers. Individ. Differ. 2015, 86, 385-389. [CrossRef]

30. Kaur, S.; Kumar, V. Academic Resilience Among Senior Secondary Students: Influence of Metacognition, Self Efficacy and Learning Environment. Ph.D. Thesis, Lovely Professional University, Phagwara, Punjab, India, 2017.

31. Widlund, A.; Tuominen-Soini, H.; Tapola, A.; Korhonen, J. Gendered pathways from academic performance, motivational beliefs, and school burnout to adolescents' educational and occupational aspirations. Learn. Instr. 2020, 66, 101299. [CrossRef]

32. Rau, P.L.P.; Gao, Q.; Wu, L.M. Using mobile communication technology in high school education: Motivation, pressure, and learning performance. Comput. Educ. 2008, 50,1-22. [CrossRef]

33. Stage, F.K. Motivation, academic and social integration, and the early dropout. Am. J. Educ. Res. 1989, 3, 385-402. [CrossRef]

34. Trigueros, R.; Gómez, N.N. La influencia del docente sobre la motivación, las estrategias de aprendizaje, pensamiento crítico de los estudiantes y rendimiento académico en el área de Educación Física. Psychol. Soc. Educ. 2019, 11, 137-150. [CrossRef]

35. Ku, K.Y.L.; Ho, I.T. Metacognitive strategies that enhance critical thinking. Metacogn. Learn. 2010, 5, $251-267$. [CrossRef] 
36. Vázquez, M.D.M.; Bellíon, E.M.E.; López-Chao, V. Impacto del uso de estrategias metacognitivas en la enseñanza de las matemáticas. Perfiles Educ. 2017, 158, 91-111. [CrossRef]

37. Rosen, L.D.; Lim, A.F.; Carrier, L.M.; Cheever, N.A. An empirical examination of the educational impact of text message-induced task switching in the classroom: Educational implications and strategies to enhance learning. Educ. Psychol. 2011, 2, 163-177.

38. Shannon, S.V. Using metacognitive strategies and learning styles to create self-directed learners. Inst. Learn. Styles J. 2008, 1, 14-28.

39. Va der Walt, M.; Maree, K. Do mathematics learning facilitators implement metacognitive strategies? S. Afr. J. Educ. 2007, 2, 12-21.

40. Vivanco, V. La adquisición de vocabulario en una segunda lengua: Estrategias cognitivas y lazos afectivos. Encuentro Rev. Investig. Innov. Clase Idiom. 2001, 12, 177-187.

41. Cassidy, S. The academic resilience scale (ARS-30): A new multidimensional construct measure. Front. Psychol. 2016, 7, 1787. [CrossRef]

42. Trigueros, R.; Magaz-González, A.M.; Tascón, M.G.; Alias, A.; Aguilar-Parra, J.M. Validation and adaptation of the academic-resilience scale in the spanish context. Int. J. Environ. Res. Public Health 2020, 11, 3779. [CrossRef]

43. Fennema, E.; Sherman, J.A. Fennema-Sherman mathematics attitudes scales: Instruments designed to measure attitudes toward the learning of mathematics by females and males. J. Res. Math. Educ. 1976, 5, 324-326. [CrossRef]

44. Vansteenkiste, M.; Sierens, E.; Soenens, B.; Luyckx, K.; Lens, W. Motivational profiles from a self-determination perspective: The quality of motivation matters. J. Educ. Psychol. 2009, 3, 671-688. [CrossRef]

45. Trigueros, R.; Aguilar-Parra, J.M.; Fernández-Campoy, J.M.; Méndez-Aguado, C. Adaptación y validación de la escala de motivación académica en secundaria con la incorporación de la regulación integrada y la desmotivación. In Innovación Educativa en la Sociedad Digital; Dykinson: Madrid, Spain, 2020.

46. Vallerand, R.J. Intrinsic and extrinsic motivation in sport and physical activity: A review and a look at the future. Handb. Sport Psychol. 2007, 3, 59-83. [CrossRef]

47. Pintrich, P.R.; Smith, D.; Garcia, T.; McKeachie, W.J. A Manual for the Use of the Motivated Strategies for Learning Questionnaire (MSLQ); National Centre for Research to Improve Postsecondary Teaching and Learning: Ann Arbor, MI, USA, 1991.

48. Roces, C.; Tourón, J.; González Torres, M.C. Validación preliminar del CEAM II. Psicológica 1995, 16, 347-366.

49. Hair, J.; Black, W.; Babin, B.; Anderson, R. Multivariate Data Analysis; Prentice-Hall, Inc.: Upper Saddle River, NJ, USA, 2010.

50. Marsh, H.W.; Hau, K.T.; Wen, Z. In search of golden rules: Comment on hypothesis-testing approaches to setting cutoff values for fit indexes and dangers in overgeneralizing hu and bentler's (1999) findings. Struct. Equ. Model 2004, 11, 320-341. [CrossRef]

51. Cicchetti, D.V.; Sparrow, S.A. Developing criteria for establishing interrater realibility for specific 284 items: Applications to assessment for adaptive behaviour. Am. J. Met. Defic. 1981, 86, 127-137.

52. Larkin, K.; Jorgensen, R. 'I Hate Maths: Why Do We Need to Do Maths?' Using iPad video diaries to investigate attitudes and emotions towards mathematics in year 3 and year 6 students. Int. J. Sci. Math. Educ. 2015, 14, 925-944. [CrossRef]

53. Hamid, M.H.S.; Shahrill, M.; Matzin, R.; Mahalle, S.; Mundia, L. Barriers to mathematics achievement in brunei secondary school students: Insights into the roles of mathematics anxiety, self-esteem, proactive coping, and test stress. Int. Educ. Stud. 2013, 6, 1-14. [CrossRef]

54. Johnston-Wilder, S.; Brindley, J.; Dent, P. Technical Report: A Survey of Mathematics Anxiety and Mathematical Resilience amongst Existing Apprentices; University of Warwick: Coventry, UK, 2014.

55. Trigueros, R.; Padilla, A.M.; Aguilar-Parra, J.M.; Rocamora-Pérez, P.; Morales-Gázquez, M.J.; López-Liria, R. The influence of emotional intelligence on resilience, test anxiety, academic stress and the Mediterranean diet. A study with university students. Int. J. Environ. Res. Public Health 2020, 6, 2071. [CrossRef]

56. De La Fuente, J.; Fernández-Cabezas, M.; Cambil, M.; Vera, M.M.; González-Torres, M.C.; Artuch-Garde, R. Linear relationship between resilience, learning approaches, and coping strategies to predict achievement in undergraduate students. Front. Psychol. 2017, 8, 1039. [CrossRef]

57. Field, A.; Evans, D.; Bloniewski, T.; Kovas, Y. Predicting maths anxiety from mathematical achievement across the transition from primary to secondary education. R. Soc. Open Sci. 2019, 11, 191459. [CrossRef] 
58. Lai, Y.; Zhu, X.; Chen, Y.; Li, Y. Effects of mathematics anxiety and mathematical metacognition on word problem solving in children with and without mathematical learning difficulties. PLOS ONE 2015, 6, e0130570. [CrossRef]

59. Tok, Şükran Effects of the know-want-learn strategy on students' mathematics achievement, anxiety and metacognitive skills. Metacogn. Learn. 2013, 2, 193-212. [CrossRef]

60. Trigueros, R.; Aguilar Parra, J.M.; Lopez-Liria, R.; Cangas, A.J.; González, J.J.; Álvarez, J.F. The role of the teacher in the students' motivation and emotions. The impact on metacognition strategies and academic performance in maths and English classes. Front. Psychol. 2019, 10, 2794. [CrossRef] [PubMed]

61. Berger, J.L.; Karabenick, S.A. Motivation and students' use of learning strategies: Evidence of unidirectional effects in mathematics classrooms. Learn. Instr. 2011, 21, 416-428. [CrossRef]

62. Rodríguez, S.; Piñeiro, I.; Gómez-Taibo, M.L.; Regueiro, B.; Estévez, I.; Valle, A. An explanatory model of maths achievement: Perceived parental involvement and academic motivation. Psicothema 2017, 2, 184-190.

63. Schmeck, R.R. Learning Strategies and Learning Styles; Prenum Press: New York, NY, USA, 1988.

64. Zimmerman, B.J. Investigating self-regulation and motivation: Historical background, methodological developments, and future prospects. Am. Educ. Res. J. 2008, 1, 166-183. [CrossRef]

65. Jagušt, T.; Botički, I.; So, H.J. Examining competitive, collaborative and adaptive gamification in young learners' math learning. Comput. Educ. 2018, 125, 444-457. [CrossRef]

66. Lo, C.K.; Hew, K.F.; Chen, G. Toward a set of design principles for mathematics flipped classrooms: A synthesis of research in mathematics education. Educ. Res. Rev. 2017, 22, 50-73. [CrossRef]

(C) 2020 by the authors. Licensee MDPI, Basel, Switzerland. This article is an open access article distributed under the terms and conditions of the Creative Commons Attribution (CC BY) license (http://creativecommons.org/licenses/by/4.0/). 